\title{
Sensitivity of Zebrafish (Danio rerio) Embryos to Hospital Effluent Compared to Daphnia magna and Aliivibrio fischeri
}

\author{
Martina WITTLEROVÁ ${ }^{1}$, Gabriela JÍROVÁ ${ }^{1,2}$, Alena VLKOVÁ ${ }^{1,2}$, Kristina KEJLOVÁ ${ }^{1}$, \\ Marek MALÝ ${ }^{1}$, Tuula HEINONEN ${ }^{3}$, Zdeňka WITTLINGEROVÁ ${ }^{2}$, Magdaléna ZIMOVÁ ${ }^{1,2}$ \\ ${ }^{1}$ National Institute of Public Health, Prague, Czech Republic, ${ }^{2}$ Faculty of Environmental Sciences, \\ Czech University of Life Sciences Prague, Prague, Czech Republic, ${ }^{3}$ Faculty of Medicine and \\ Health Technology, Tampere University, Tampere, Finland
}

Received October 8, 2020

Accepted November 26, 2020

\section{Summary}

The Fish Embryo Acute Toxicity (FET) Test was adopted by the Organisation for Economic Co-operation and Development as OECD TG 236 in 2013. The test has been designed to determine acute toxicity of chemicals on embryonic stages of fish and proposed as an alternative method to the Fish Acute Toxicity Test performed according to OECD TG 203. In recent years fish embryos were used not only in the assessment of toxicity of chemicals but also for environmental and wastewater samples. In our study we investigated the acute toxicity of treated wastewater from seven hospitals in the Czech Republic. Our main purpose was to compare the suitability and sensitivity of zebrafish embryos with the sensitivity of two other aquatic organisms commonly used for wastewater testing - Daphnia magna and Aliivibrio fischeri. For the aim of this study, in addition to the lethal endpoints of the FET test, sublethal effects such as delayed heartbeat, lack of blood circulation, pericardial and yolk sac edema, spinal curvature and pigmentation failures were evaluated. The comparison of three species demonstrated that the sensitivity of zebrafish embryos is comparable or in some cases higher than the sensitivity of $D$. magna and $A$. fischeri. The inclusion of sublethal endpoints caused statistically significant increase of the FET test efficiency in the range of 1-12 \%. Based on our results, the FET test, especially with the addition of sublethal effects evaluation, can be considered as a sufficiently sensitive and useful additional tool for ecotoxicity testing of the acute toxicity potential of hospital effluents.

\section{Key words}

Fish Embryo Toxicity (FET) test • Hospital wastewater • Acute toxicity $\bullet$ Aquatic organisms $\bullet$ Sublethal endpoints

\section{Corresponding author}

G. Jírová, National Institute of Public Health, Šrobárova 49/48, 10000 Praha 10, Czech Republic. E-mail: gabriela.jirova@szu.cz

\section{Introduction}

The Fish Embryo Acute Toxicity Test (FET test) was adopted by the Organisation for Economic Co-operation and Development as OECD TG 236 in 2013 (OECD 2013). The method using fish embryos as the testing organisms has been primary designed to determine acute toxicity of chemicals. Fish embryos as non-feeding developmental stages are not categorized as protected vertebrates according to the European Directive 2010/63/EU on the protection of animals used for scientific purposes (European Parliament and Council 2010). Therefore, the FET test is considered as an alternative to experiments with adult fish with a good correlation with the Fish Acute Toxicity Test by OECD TG 203 (OECD 2019) as reported in studies by Lammer et al. (2009) and Dang et al. (2017). Recently, its use has been extended also to the assessment of complex mixtures (e.g. environmental samples, wastewater (WW), construction products). The zebrafish embryos represent a useful model with a wide range of possible applications in environmental hazard and risk assessment (Scholz et al. 2008). However, the FET test sensitivity to substances is variable and its applicability domain has not yet been fully defined (Dang et al. 2017, Sobanska et al. 2017).

Hospital wastewater (HWW) is a source of

PHYSIOLOGICAL RESEARCH • ISSN 1802-9973 (online) 
diverse pollutants which may have negative impact mainly on the aquatic environment (Pérez-Alvarez et al. 2018). Hospital effluents are prone to higher ecotoxicological potential than urban wastewater (Laquaz et al. 2017). This fact is due to the content of wider spectrum and higher quantity of pharmaceutical compounds (Santos et al. 2010, Wiest et al. 2018) and other chemicals. In their review Orias and Perrodin (2013) highlighted a great diversity of the substances present within hospital effluents, and in some cases their high ecotoxicity. Due to the requirements of the EU Water Framework Directive (European Parliament and Council 2000), the quality of surface waters in the EU has been constantly improving in recent decades. One of the main objectives is to improve the treatment processes at WW treatment plants aiming to significantly reduce the discharge of undesirable substances, including pharmaceuticals, pesticides, industrial substances and human care products. Although HWW is mostly treated by WW treatment plants before discharge into the sewage system or the environment, numerous pharmaceuticals and other chemicals are insufficiently removed during treatment and end up in surface water (Wigh et al. 2016, Välitalo et al. 2017). Therefore, in our research we investigated HWW to evaluate the efficacy of the treatment processes within the Czech Republic. Moreover, WW samples were selected from different hospital types and sizes with the intention to consider the variability of their composition.

In the review focused on conventional and alternative bioassays suitable for ecotoxicological evaluation of WW, Jirova et al. (2016) highlighted the need to supplement the conventional methods (based on bacteria, algae, crustaceans, fish and seeds) with the FET test as an alternative approach to vertebrate ecotoxicity tests and a useful tool for efficient detection of acute toxicity. However, scientific data regarding the sensitivity and suitability of the FET test for hospital effluent testing are scarce so far. Therefore, the primary objective of our study was to extend knowledge of this issue and make a comparative assessment of the tests based on the zebrafish embryos and other used aquatic species.

For the determination of ecotoxicity of WW from health care facilities, a battery of three bioassays with Daphnia magna (ISO 6341), Alivivibrio fischeri (ISO 11348-2) and Desmodesmus subspicatus (ISO 8692) is recommended by the Czech standard ČSN 756406 (2020). In the study investigating treated effluents from five different hospitals, Jirova et al. (2018) concluded that the battery of three species consisting of D. magna, A. fischeri and D. subspicatus may be appropriate for routine testing of ecotoxicological potential of hospital effluents. For our purpose, based on the conclusions of foregoing and numerous other studies (Abbas et al. 2018, Ellepola et al. 2020, Laquaz et al. 2017, Li et al. 2017, Vasconcelos et al. 2017), D. magna and A. fischeri were selected as sufficiently sensitive comparative test organisms.

The international standard ISO 15088 was adopted in 2007 and its merit is to determine acute toxicity of WW to zebrafish eggs after $48 \mathrm{hpf}$ (hours post fertilization) of exposure. Therefore, in the present study we compared the results of two final test exposure times $48 \mathrm{hpf}$ (according to the ISO 15088) and $96 \mathrm{hpf}$ (according to the FET test).

Based on their experience with the FET test, many authors recommend the inclusion of further endpoints to increase the sensitivity of the assay. Braunbeck et al. (2015) recommended more research to better define the domain of applicability of the FET test and suggested modifications of the method with addition of more endpoints for the detection of a multitude of toxic effects. In a comparative study, Stelzer et al. (2018) indicated the need to complement the FET test with sublethal metrics which would increase its efficiency, and also highlighted the necessity to validate this statement by further studies using other WW samples. For the aim of our study, in addition to the lethal endpoints of the FET test (coagulated embryos, lack of somite formation, non-detachment of the tail and lack of heartbeat), sublethal effects comprising delayed heartbeat, lack of blood circulation, pericardial and yolk sac edema, spinal curvature and pigmentation failures were evaluated.

In this study the WW samples from seven different hospitals were investigated to compare the suitability and sensitivity of zebrafish embryos with the sensitivity of two other aquatic organisms - D. magna and A. fischeri. Other purposes were to evaluate the sensitivity of the FET test after inclusion of sublethal parameters and to confirm the increase in efficiency of the method after prolongation of exposure time.

\section{Methods}

\section{Wastewater samples}

The samples were collected in 2019 from the outlets of WW treatment plants of seven different 
hospitals located in the central, southern and eastern regions of the Czech Republic. Table 1 shows general characteristics of the hospitals and their WW treatment plants. The sample $\mathrm{H} 1$ was a mixture of treated HWW and untreated hospital laundry WW. One sample was taken from each hospital. The samples were collected after treatment activities before discharging into the urban sewer system, stored in cooling boxes, transported to the laboratory and deep frozen at $\leq 18{ }^{\circ} \mathrm{C}$ prior to analysis.

Table 1. Characteristics of hospitals and their wastewater treatment plants.

\begin{tabular}{lccccc}
\hline Hospital & $\begin{array}{c}\text { Type of } \\
\text { hospital }\end{array}$ & $\begin{array}{c}\text { Sizing } \\
\text { (beds) }\end{array}$ & $\begin{array}{c}\text { Wastewater } \\
\text { treatment process }\end{array}$ & $\begin{array}{c}\text { Wastewater } \\
\text { generation }\left(\mathbf{m}^{\mathbf{3}} \cdot \mathbf{d}^{-\mathbf{1}} \mathbf{)}\right.\end{array}$ & $\begin{array}{c}\text { Disinfection } \\
\text { process }\end{array}$ \\
\hline$H 1$ & General & 476 & Mechanical-Biological & 10 & $\mathrm{Cl}_{2}$ \\
$H 2$ & University & 1006 & Mechanical-Biological & 50 & $\mathrm{NaClO}$ \\
$H 3$ & University & 2199 & Mechanical-Biological & $50-100$ & $\mathrm{NaClO}$ \\
$H 4$ & General & 500 & Mechanical-Biological & $30-50$ & $\mathrm{Cl}_{2}$ \\
$H 5$ & General & 423 & Mechanical-Biological & 40 & $\mathrm{Do} \mathrm{not} \mathrm{chlorinate}^{\mathrm{Cl}_{2}}$ \\
$H 7$ & General & 1447 & Mechanical-Biological & 360 & $\mathrm{NaClO}$ \\
\hline
\end{tabular}

\section{Ecotoxicological tests}

Ecotoxicological potential of hospital WW was described using three organisms which represented three trophic levels: A. fischeri (formerly Vibrio fischeri) as a decomposer, D. magna as a primary consumer and Danio rerio as a secondary consumer. Characteristics of bioassays used in the study are summarized in Table 2.

As a first step, undiluted samples were analyzed by means of D. magna and D. rerio assays. In the case of A. fischeri test, $80 \%$ concentration of the sample was used in accordance with the method procedure. The results were expressed as percentage of toxic effect on each species.

If the values of toxic effect exceeded $50 \%, \mathrm{EC}_{50}$ or $\mathrm{LC}_{50}$ (effective or lethal concentration of the sample that caused negative impact in $50 \%$ of the tested organisms) were calculated by the probit method. The experiments were conducted using a series of increasing concentrations depending on the level of HWW toxicity.

Every test was performed in two independent runs and the results were expressed as mean.

Table 2. Characteristics of bioassays used in the study.

\begin{tabular}{|c|c|c|c|c|}
\hline Method & Organism & Standard & $\begin{array}{l}\text { Exposure } \\
\text { time }\end{array}$ & Endpoint \\
\hline $\begin{array}{l}\text { Daphnia immobilization test } \\
\text { (D. magna) }\end{array}$ & Daphnia magna & ISO 6341 & $48 \mathrm{~h}$ & $\begin{array}{c}\text { Immobility [\%] } \\
\mathrm{EC}_{50}[\%]\end{array}$ \\
\hline $\begin{array}{l}\text { Luminescence inhibition test } \\
\text { (A. fischeri } 15 \text { min, } 30 \mathrm{~min} \text { ) }\end{array}$ & Aliivibrio fischeri & ISO $11348-2$ & $\begin{array}{l}15 \min \\
30 \min \end{array}$ & $\begin{array}{l}\text { Luminescence inhibition }[\%] \\
\qquad \mathrm{EC}_{50}[\%]\end{array}$ \\
\hline $\begin{array}{l}\text { FET test } \\
(\text { FET } 48 h)\end{array}$ & $\begin{array}{c}\text { Danio rerio } \\
\text { embryo }\end{array}$ & OECD TG 236 & $48 \mathrm{hpf}$ & $\begin{array}{l}\text { Mortality [\%] } \\
\qquad \mathrm{LC}_{50}[\%]\end{array}$ \\
\hline $\begin{array}{l}\text { FET test } \\
(\text { FET } 96 h)\end{array}$ & $\begin{array}{l}\text { Danio rerio } \\
\text { embryo }\end{array}$ & OECD TG 236 & $96 \mathrm{hpf}$ & $\begin{array}{l}\text { Mortality }[\%] \\
\operatorname{LC}_{50}[\%]\end{array}$ \\
\hline $\begin{array}{l}\text { FET test } \\
(\text { FET } 96 h+s u b)\end{array}$ & $\begin{array}{l}\text { Danio rerio } \\
\text { embryo }\end{array}$ & $\begin{array}{c}\text { OECD TG } 236 \\
\text { modified }\end{array}$ & $96 \mathrm{hpf}$ & $\begin{array}{c}\text { Mortality }+ \text { sublethal effects }[\%] \\
\mathrm{LC}_{50}[\%]\end{array}$ \\
\hline
\end{tabular}

hpf: hours post fertilization. 


\section{Fish Embryo Acute Toxicity (FET) test}

The FET test was performed according to OECD TG 236 (OECD 2013). Three different protocols of the method were carried out: the test with basic exposure time $96 \mathrm{hpf}$ (hours post fertilization), the test with reduction of exposure time to $48 \mathrm{hpf}$ and the test with addition of five sublethal endpoints with exposure time 96 hpf.

The breeding stock of $\mathrm{AB}$ line of $D$. rerio wild type was maintained in Zebrafish Housing System ZebTEC Stand-Alone (Tecniplast) with continuous treatment and monitoring of important water parameters including $\mathrm{pH}$, conductivity and temperature. Mature zebrafish aged between 6 and 18 months were used to obtain fertilized fish eggs, which were collected from a minimum of three breeding groups and selected for testing at random.

Spawning took place in two-liter breeding tanks which capitalize on the fish natural tendency to spawn in shallow water. After spawning, the eggs were rinsed with maintenance water adjusted to $\mathrm{pH} 6.5$ to 7.5 and final hardness 70 to $100 \mathrm{mg} \cdot l^{-1} \mathrm{CaCO}_{3}$. The eggs were checked under inverted microscope. Viable embryos maximally at the 16 cell-stage without obvious irregularities were individually placed into polystyrene 24-well plates and incubated under $26 \pm 1{ }^{\circ} \mathrm{C}$ with 16:8 light:dark cycle. Each well contained $2 \mathrm{ml}$ of test solution. Five sample concentrations were prepared in each test run. 20 eggs per concentration were exposed to the samples. Dilution water with a final concentration of $294.0 \mathrm{mg} \cdot 1^{-1} \mathrm{CaCl}_{2} \times 2 \mathrm{H}_{2} \mathrm{O}$, $123.3 \mathrm{mg} \cdot 1^{-1} \quad \mathrm{MgSO}_{4} \times 7 \mathrm{H}_{2} \mathrm{O}, \quad 63.0 \mathrm{mg} \cdot 1^{-1} \quad \mathrm{NaHCO}_{3}$, $5.5 \mathrm{mg} \cdot 1^{-1} \mathrm{KCl}$ (as defined in ISO 7346-2) was used for the preparation of the test concentrations and negative controls. The sensitivity of embryos was controlled by 3,4-dichloroaniline $(4 \mathrm{mg} / \mathrm{l})$ as positive control in each test run. All experiments were carried out in a static way without change of exposure solution. The test was considered as valid when oxygen concentration was maintained above $80 \%$ during the test and mortality in the negative controls did not exceed $10 \%$.

Embryos were observed for four lethal and five sublethal effects. Lethal parameters described in the OECD TG 236 (OECD 2013) comprised coagulation of embryos, lack of somite formation, non-detachment of the tail and lack of heartbeat. Added sublethal endpoints included delayed heartbeat, lack of blood circulation, presence of edema (pericardial or yolk sac), spinal curvature and pigmentation failures. Examples of the observed sublethal effects are illustrated in Figure 1. Embryos placed in the culture plates were examined separately using inverted microscope Olympus CKX53 equipped with a digital camera Canon EOS 2000D. For determination of heart rate, embryos were video recorded and heartbeat was counted when the video was slowed down. The heart rate of embryos exposed to the samples was evaluated in relation to the negative control groups.

The cumulative mortality of zebrafish embryos was recorded at $48 \mathrm{hpf}$ (termed FET $48 \mathrm{~h}$ ) and $96 \mathrm{hpf}$ (termed FET $96 \mathrm{~h}$ ) in experimental and control groups. The results were calculated as percentage of mortality (toxic effect) of the tested embryos, or as $\mathrm{LC}_{50}$.

After the addition of sublethal effects to the lethal endpoints, the embryos development was evaluated at $96 \mathrm{hpf}$ (termed FET $96 \mathrm{~h}+\mathrm{sub}$ ). Sublethal criteria were counted only if lethal parameters were not observed. The results were calculated as percentage of toxic effects on the tested embryos, or as $\mathrm{EC}_{50}$.

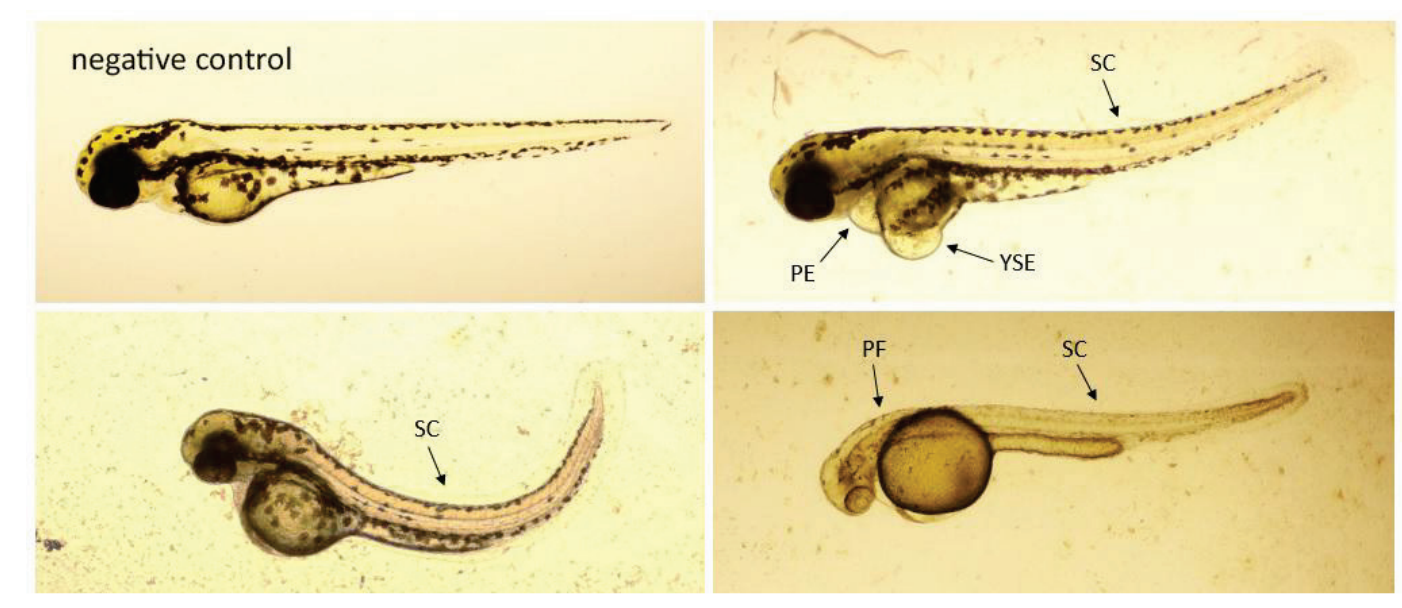

Fig. 1. Representative sublethal abnormalities of zebrafish embryos after 96 hpf (hours post fertilization) exposure to the hospital wastewater samples. $\mathrm{PE}=$ pericardial edema, $\mathrm{YSE}=$ yolk sac edema, $\mathrm{SP}=$ spinal curvature, $\mathrm{PF}=$ pigmentation failure. 


\section{Daphnia immobilization test}

The acute toxicity test with $D$. magna Straus was carried out according to ISO 6341 (2012). Neonates (less than $24 \mathrm{~h}$ old specimens of D. magna) of at least third generation originated from laboratory culture were exposed to five designated dilutions of samples. 20 organisms were placed in each concentration and negative control (dilution water according to ISO 6341 was identical to the dilution water used in the FET test mentioned above) and incubated $48 \mathrm{~h}$ under the following test conditions: temperature $20 \pm 2{ }^{\circ} \mathrm{C}, 16: 8$ light:dark cycle, oxygen concentration $\geq 2 \mathrm{mg} \cdot \mathrm{l}^{-1}$, no feeding. For the experiment validity, the inhibition of mobility in the negative controls had to be $\leq 10 \%$. The sensitivity of test organisms was monitored by regular tests with $\mathrm{K}_{2} \mathrm{Cr}_{2} \mathrm{O}_{7}$ used as positive control.

The results were expressed as percentage of Daphnia immobilization (toxic effect), or as $\mathrm{EC}_{50}$ after $48 \mathrm{~h}$ exposure.

\section{Aliivibrio bioluminescence inhibition test}

The luminescent bacteria test followed ISO 11348-2 (2007). The test was performed using liquid-dried bacteria A. fischeri NRRL-B-11177 (HACH LANGE). Bacteria were activated by rehydration with reactivation solution. For the experiments, the conductivity of the samples was $>10 \mathrm{mS} \cdot \mathrm{cm}^{-1}, \mathrm{pH} 6.0$ to 8.5 and oxygen concentration $>3 \mathrm{mg} \cdot \mathrm{l}^{-1}$. $2 \% \mathrm{NaCl}$ solution was used as dilution water and negative control. The suspensions of bacteria and diluted samples (ten sample concentrations in replicates) were incubated at $15 \pm 1{ }^{\circ} \mathrm{C}$. Luminescence was measured after $15 \mathrm{~min}$ and 30 min of exposure to the sample concentrations series by luminometer Sirius (Berthold Detection Systems). The bacteria sensitivity was controlled using positive control $\left(\mathrm{ZnSO}_{4} \times 7 \mathrm{H}_{2} \mathrm{O}\right)$.

The results were presented as percentage of inhibition of the bacteria light emission (toxic effect) with respect to the negative control, or as $\mathrm{EC}_{50}$.

\section{Statistical analysis}

Linear mixed model was used to evaluate the results of the monitoring of wastewater ecotoxicity and to assess the difference between methods (fixed effect) while taking into account the variability between hospitals (random effect). The dependent variable was angularly transformed percentage (of toxic effect). Transformed percentages more closely approximate the normal distribution (Sokal and Rohlf 1995). When statistically significant effects were identified, Šidák's multiple comparisons procedure was applied to ascertain which specific methods differed. Values of $p<0.05$ were considered as indicating a statistically significant result. All statistical analyses were performed using Stata software package, release 14.2 (Stata Corp LP, College Station, TX, USA).

\section{Results}

Comparison of the methods sensitivity based on the toxic effects values

To compare the sensitivity of three aquatic species to the acute toxicity of HWW, the samples from seven different hospitals were investigated. In the first part of the study, the percentage of immobility (D. magna), luminescence inhibition (A.fischeri), mortality and sublethal effects (D. rerio embryos) after exposure to HWW samples were expressed as toxic effects. The results are shown in Figure 2a. The obtained data demonstrated highly variable toxic impact of hospital effluents on the studied organisms. The tests FET $96 \mathrm{~h}$ and FET $96 \mathrm{~h}+$ sub indicated high sensitivity of zebrafish embryos to five samples out of seven samples (i.e. H1, H3-H6) with toxic effect values in the range of $62.5-100 \%$. The results of other methods for these five samples were more variable with values ranging from $0 \%$ to $100 \%$ of crustacean immobility and fish embryo mortality (FET $48 \mathrm{~h}$ ) and from $0 \%$ to $98.4 \%$ of bacteria luminescence inhibition. Based on the results of all samples, no statistically significant differences were found between FET tests (FET $48 \mathrm{~h}$, FET $96 \mathrm{~h}$, FET $96 \mathrm{~h}+\mathrm{sub})$ and D. magna test $(\mathrm{p}=0.123, \mathrm{p}=0.507$, $\mathrm{p}=0.275$ respectively). However, the results showed statistically significant differences between FET $96 \mathrm{~h}$ and A. fischeri $15 \mathrm{~min}, \quad 30 \mathrm{~min} \quad(\mathrm{p}=0.018, \quad \mathrm{p}=0.024$ respectively) and between FET $96 \mathrm{~h}+$ sub and $A$. fischeri $15 \min , 30 \min (\mathrm{p}=0.006, \mathrm{p}=0.008$ respectively).

Comparison of methods sensitivity based on the EC50, LC50 values

In the following study, if the values of toxic effect exceeded $50 \%(\mathrm{H} 1, \mathrm{H} 3-\mathrm{H} 6), \mathrm{EC}_{50}$ or $\mathrm{LC}_{50}$ values were calculated. The results are presented in Figure $2 \mathrm{~b}$. In the case of samples which were assessed as the most toxic and which negatively affected the majority of the test species $(\mathrm{H} 1, \mathrm{H} 3, \mathrm{H} 6)$, D. magna was the most sensitive organism with $\mathrm{EC}_{50}$ values ranging from 4.5 to $37.6 \%$. The method sensitivity to the samples $\mathrm{H} 1$ and 
H3 decreased in the following order: D. magna $>$ FET $96 \mathrm{~h}+$ sub $>$ FET $96 \mathrm{~h}>$ A. fischeri $15 \mathrm{~min}>$ FET $48 \mathrm{~h}$ and to sample H6: D. magna $>$ A. fischeri $15 \mathrm{~min}>A$. fischeri $30 \mathrm{~min}>$ FET tests.

\section{Comparison within the FET tests}

When we made a comparison within the different protocols of the FET test, a decreasing sensitivity of each method was observed as follows: FET $96 \mathrm{~h}+$ sub $>$ FET $96 \mathrm{~h}>$ FET $48 \mathrm{~h}$. Mortality was manifested most frequently by lack of heartbeat, growth retardation, and less commonly by coagulation of embryos. As shown in Figure $2 b$, the inclusion of sublethal endpoints has reduced the $\mathrm{LC}_{50}$ values for all samples with statistically significant increment of the FET test sensitivity $(p=0.026)$ in the range of $1-12 \%$. The presence of sublethal effects was variable not only between different samples but it also varied depending on the exposure time (Table 3). Prolonged exposure time caused a statistically significant increase of the zebrafish embryos sensitivity $(\mathrm{p}<0.001)$ in $57 \%$ of the tested samples. The frequency of occurrence of sublethal criteria was: spinal curvature $34.5 \%$, lack of blood circulation $26.4 \%$, delayed heartbeat $25.7 \%$, pigmentation failures $12.7 \%$, occurrence of edema $0.7 \%$ of all sublethal parameters we observed. According to Kimmel et al. (1995), embryos development in control groups was normal during all the experiments.

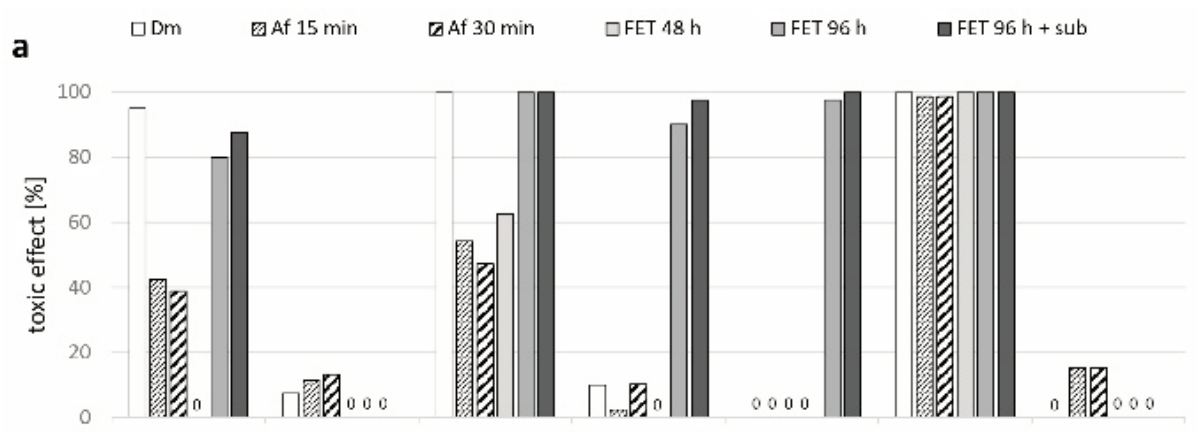

Fig. 2. Ecotoxicity of wastewater samples from different hospitals (H1-H7) expressed as: (a) toxic effect [\%] of undiluted samples and (b) $\mathrm{EC}_{50}, \mathrm{LC}_{50}$ values [\%]. Comparison between Daphnia magna (Dm), Aliivibrio fischeri (Af) and Danio rerio embryos. FET=Fish Embryo Acute Toxicity Test.

b

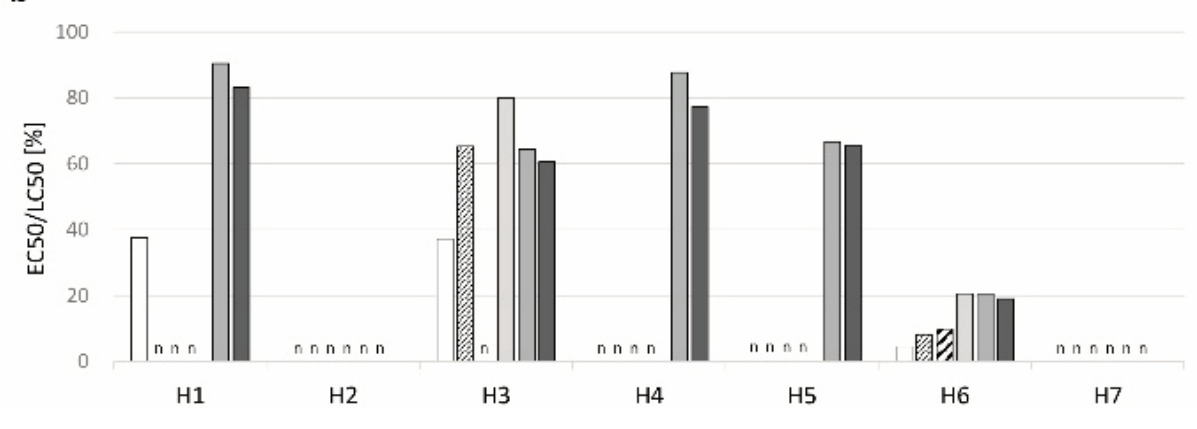

Table 3. Overview of the observed sublethal effects on zebrafish embryos after $48 \mathrm{hpf}$ and $96 \mathrm{hpf}$ (hours post fertilization) exposure to the wastewater samples from different hospitals $(\mathrm{H} 1-\mathrm{H} 7)$. Sublethal effects were measured only if lethal effects were not observed.

\begin{tabular}{llllclll}
\hline Sublethal effects & H1 & $\mathbf{H 2}$ & $\mathbf{H 3}$ & $\begin{array}{c}\mathbf{H 4} \\
\mathbf{4 8} \mathbf{~ h p f} / \mathbf{9 6} \mathbf{~ h p f}\end{array}$ & $\mathbf{H 5}$ & $\mathbf{H 6}$ & $\mathbf{H 7}$ \\
\hline Delayed heartbeat & $-/+$ & $-/-$ & $+/+$ & $-/+$ & $-/+$ & $+/+$ & $-/-$ \\
Lack of blood circulation & $-/+$ & $-/-$ & $+/+$ & $-/+$ & $-/+$ & $+/+$ & $-/-$ \\
Presence of edema & $-/+$ & $-/-$ & $+/+$ & $-/+$ & $-/+$ & $-/-$ & $-/-$ \\
Spinal curvature & $-/+$ & $-/-$ & $+/+$ & $-/+$ & $-/+$ & $-/+$ & $-/-$ \\
Pigmentation failures & $-/+$ & $-/-$ & $+/+$ & $-/+$ & $-/+$ & $+/+$ & $-/-$ \\
\hline
\end{tabular}

- not observed, + observed. 


\section{Discussion}

The problem of the discharge of chemical contaminants from hospitals into wastewater and subsequently into the aquatic ecosystems is well-known (Datel et al. 2020). The presence of micropollutants such as pharmaceuticals, disinfectants and personal care products in treated effluents poses considerable ecological risk for the aquatic environment (Meza et al. 2020, Rogowska et al. 2020). Numerous studies have been carried out to determine ecotoxicity of target substances commonly detected in HWW (HallingSörensen et al. 2000, Cleuvers 2003, Cleuvers 2005, Brandhof et al. 2010, Martins et al. 2012, Li et al. 2016, Romanucci et al. 2019). However, examination of individual target compounds, causing ecotoxicity does not enable to determine the interactions between all known and unknown hazardous substances which are present in HWW and to evaluate their overall impact on aquatic organisms. The mixture of two or more substances may produce synergistic, antagonistic and additive interactions which may increase or decrease the resulting WW ecotoxicity (Emmanuel et al. 2005, Godoy et al. 2019).

Therefore, it is necessary to investigate the whole effluent as a complex mixture of substances. In our present study a high variability of toxic effects of WW samples from individual hospitals on the used aquatic organisms was demonstrated. Similarly to these conclusions, Jírová et al. (2018) confirmed considerable different levels of ecotoxicity of treated wastewater from five hospitals. This variability relates to the different wastewater quality which may be influenced by a number of factors comprising current therapeutic procedures, the type and specialization of the hospital, its location, number of inpatients, flow rate, season, the day of the week and the daily period (Boillot et al. 2008). Good correlation was demonstrated between the amount of antibiotics in the wastewater and their volume currently being administered to patients (Hamjinda et al. 2015). Additionally, the insufficient degradability of certain substances during the cleaning process in the wastewater treatment plants causes the presence of residues of pollutants in wastewater ( $\mathrm{Li}$ et al. 2017). A literary review showed that the quality of treatment processes is another important factor which affects the treated wastewater composition (Verlicchi et al. 2015).

A specific type of effluents is generated from the hospital laundry. It has a different composition from WW produced by other hospital departments having a high concentration of organic and microbial loads depending on the washing stage. In the study of Kern et al. (2015), acute toxicity of hospital laundry WW was investigated by $D$. magna immobilization test and adult D. rerio lethality test. The obtained data showed extremely toxic impact on D. magna (48 $\mathrm{h} \mathrm{EC}_{50}=2.01 \%$ ) and lower acute toxicity for $D$. rerio $\left(48 \mathrm{~h} \mathrm{LC}_{50}=29.25 \%\right.$ ). In our study, the sample that can be considered as the most toxic (H6) because of its low $\mathrm{EC}_{50}$ and $\mathrm{LC}_{50}$ values (Fig. 1), was the mixture of treated hospital WW and untreated laundry WW before discharging to the sewage system. It can be assumed that the high level of acute toxicity was caused by the complement of untreated laundry effluent to common HWW.

Ecotoxicological evaluation of WW should be performed using the battery of indicator organisms from different trophic levels as different species may show diverse levels of sensitivity to the pollutants. The results of our study, as well as those of Jirova et al. (2018), showed the suitability of D. magna and A. fischeri for routine testing of HWW ecotoxicity. To our knowledge, the information on effects of HWW on fish early life stages using the FET test, is scarce. Stelzer et al. (2018) compared the FET test and other standard fish protocols used worldwide for WW analyses. $\mathrm{LC}_{50}$ value of untreated hospital effluent determined by the FET test was $53.5 \%$. Based on findings of this study, the zebrafish embryos may not represent the most sensitive developmental stage of $D$. rerio compared to larvae and juvenile. In another study, a mixture of urban and hospital effluents was evaluated for ecotoxicity by Wigh et al. (2016). After $96 \mathrm{~h}$ of exposure to the untreated WW, $100 \%$ of zebrafish embryos died. The mortality decreased to $13 \%$ after the WW treatment. The addition of sublethal criteria for evaluation, such as the presence of edema, blood circulation defects, malformation of the heart, yolk sac, tail, head, spine, an abnormal eye development and pigmentation, resulted in a considerable improvement of the test efficiency.

By adding sublethal parameters, we wanted to explore the potential of the FET test for the evaluation of hospital effluent toxicity. Our conclusions are in agreement with findings of numerous studies which have reported an increase in the FET test sensitivity after addition of sublethal endpoints (Babić et al. 2017, Krzykwa et al. 2019, Cedron et al. 2020). We selected five sublethal effects, which may be easily determined: delayed heartbeat, lack of blood circulation, presence of 
edema (pericardial or yolk sac), spinal curvature and pigmentation failures. Tenorio-Chávez et al. (2020) investigated treated WW from one hospital using zebrafish embryos and obtained $\mathrm{LC}_{50}$ value $6.1 \%$. $\mathrm{EC}_{50}$ value of sublethal malformations was $2.5 \%$ which means higher sensitivity of sublethal parameters compared to lethal endpoints. The main effects identified were pericardial edema, yolk sac malformation, hypopigmentation, hatching abnormalities, tail and chorda deformation, without fin, chorion and craniofacial malformation. Stelzer et al. (2018) observed an increase in embryo test sensitivity of $>30 \%$ after addition of three sublethal parameters comprising immobility, formation of edema and nonhatching.

According to our results, when we draw a comparison between FET $48 \mathrm{~h}$ and FET $96 \mathrm{~h}$, we can see the increase in efficiency of the method caused by the prolonged exposure time from $48 \mathrm{hpf}$ to $96 \mathrm{hpf}$. In our study, the $\mathrm{LC}_{50}$ values of FET $48 \mathrm{~h}$ were constantly higher than those of FET $96 \mathrm{~h}$. We are of the opinion that these findings could be related, besides other factors, to the chorion as a possible barrier for some chemicals, mainly substances with very high molecular weight (Braunbeck et al. 2015, Sobanska et al. 2017). This limit disappears during the hatching period of embryonic development from about $72 \mathrm{hpf}$ to $96 \mathrm{hpf}$ (Kimmel et al. 1995). Similar results were presented by Stelzer et al. (2018), who, based on analyses of HWW samples, discovered less sensitivity of FET $48 \mathrm{~h}\left(\mathrm{LC}_{50}=56.5 \%\right)$ compared to FET $96 \mathrm{~h}\left(\mathrm{LC}_{50}=53.5 \%\right)$.

\section{Conclusions}

The Fish Embryo Acute Toxicity Test is used worldwide for ecotoxicological research as an alternative method to the experiments with adult fish. Considering the lack of scientific data regarding the suitability of D. rerio embryos as the testing organisms for $\mathrm{HWW}$ investigation, the main purpose of our study was to make a comparison between zebrafish embryos and two other aquatic organisms commonly used for WW analyses.

The results of our study demonstrated highly variable toxic impacts of WW samples from different hospitals on all the test species. With respect to determining acute toxicity of HWW, the obtained data indicate that the sensitivity of zebrafish embryos is comparable or in some cases higher than the sensitivity of D. magna and A.fischeri and the FET test may be considered as a sufficiently effective and appropriate method for routine HWW testing.

The prolonged exposure time of the test from $48 \mathrm{hpf}$ to $96 \mathrm{hpf}$ significantly improved the sensitivity of zebrafish embryos in $57 \%$ of the tested samples.

In addition to the lethal endpoints, five sublethal criteria were evaluated as a modification of the FET test. The inclusion of sublethal parameters comprising delayed heartbeat, lack of blood circulation, pericardial and yolk sac edema, spinal curvature and pigmentation failures caused statistically significant increase of the FET test sensitivity $(p=0.026)$ in the range of $1-12 \%$.

Our study highlights the necessity of further validation of the FET test applicability for the assessment of hospital effluents by examination of WW samples from a larger set of hospitals. The choice of a suitable battery of sublethal effects in addition to the lethal endpoints of the FET test may be recommended to extend the method efficiency.

\section{Conflict of Interest}

There is no conflict of interest.

\section{Acknowledgements}

Supported by ERDF/ESF project "International competitiveness of NIPH in research, development and education in alternative toxicological methods" (No. CZ.02.1.01/0.0/0.0/16_019/0000860).

\section{References}

ABBAS M, ADIL M, EHTISHAM-UL-HAQUE S, MUNIR B, YAMEEN M, GHAFFAR A, SHAR GA, TAHIR MA, IQBAL M: Vibrio fischeri bioluminescence inhibition assay for ecotoxicity assessment: A review. Sci Total Environ 626: 1295-1309, 2018. https://doi.org/10.1016/j.scitotenv.2018.01.066

BABIĆ S, BARIŠIĆ J, VIŠIĆ H, KLOBUČAR RS, TOPIĆ POPOVIĆ N, STRUNJAK-PEROVIĆ I, ČOŽ-RAKOVAC R, KLOBUČAR G: Embryotoxic and genotoxic effects of sewage effluents in zebrafish embryo using multiple endpoint testing. Water Res 115: 9-21, 2017. https://doi.org/10.1016/j.watres.2017.02.049

BOILLOT C, BAZIN C, TISSOT-GUERRAZ F, DROGUET J, PERRAUD M, CETRE JC, TREPO D, PERRODIN Y: Daily physicochemical, microbiological and ecotoxicological fluctuations of a hospital effluent according to technical and care activities. Sci Total Environ 403: 113-129, 2008. https://doi.org/10.1016/j.scitotenv.2008.04.037 
BRANDHOF EJ, MONTFORTS M: Fish embryo toxicity of carbamazepine, diclofenac and metoprolol. Ecotoxicol Environ Saf 73: 1862-1866, 2010. https://doi.org/10.1016/j.ecoenv.2010.08.031

BRAUNBECK T, KAIS B, LAMMER E, OTTE J, SCHNEIDER K, STENGEL D, STRECKER R: The fish embryo test (FET): origin, applications, and future. Environ Sci Pollut Res 22: 16247-16261, 2015. https://doi.org/10.1007/s11356-014-3814-7

CEDRON VP, WEINER AMJ, VERA M, SANCHEZ L: Acetaminophen affects the survivor, pigmentation and development of craniofacial structures in zebrafish (Danio rerio) embryos. Biochem Pharmacol 174: 113816, 2020. https://doi.org/10.1016/j.bcp.2020.113816

CLEUVERS M: Aquatic ecotoxicity of pharmaceuticals including the assessment of combination effects. Toxicol Lett 142: 185-194, 2003. https://doi.org/10.1016/S0378-4274(03)00068-7

CLEUVERS M: Initial risk assessment for three beta-blockers found in the aquatic environment. Chemosphere 59: 199-205, 2005. https://doi.org/10.1016/j.chemosphere.2004.11.090

ČSN 75 6406: Wastewater discharge and treatment from health facilities, 2020.

DANG Z, VAN DER VEN LTM, KIENHUIS AS: Fish embryo toxicity test, threshold approach, and moribund as approaches to implement 3R principles to the acute fish toxicity test. Chemosphere 186: 677-685, 2017. https://doi.org/10.1016/j.chemosphere.2017.08.047

DATEL JV, HRABANKOVA A: Pharmaceuticals load in the Svihov water reservoir (Czech Republic) and impacts on quality of treated drinking water. Water 12: 1387, 2020. https://doi.org/10.3390/w12051387

ELLEPOLA N, OGAS T, TURNER DN, GURUNG R, MALDONADO-TORRES S, TELLO-ABURTO R, PATIDAR PL, ROGELJ S, PIYASENA ME: A toxicological study on photo-degradation products of environmental ibuprofen: Ecological and human health implications. Ecotoxicol Environ Saf 188: 109892, 2020. https://doi.org/10.1016/j.ecoenv.2019.109892

EMMANUEL E, HANNA K, BAZIN C, KECK G, CLÉMENT B, PERRODIN Y: Fate of glutaraldehyde in hospital wastewater and combined effects of glutaraldehyde and surfactants on aquatic organisms. Environ Int 31: 399-406, 2005. https://doi.org/10.1016/j.envint.2004.08.011

EUROPEAN PARLIAMENT AND COUNCIL: DIRECTIVE 2000/60/EC of the European Parliament and of the Council establishing a framework for Community action in the field of water policy (EU Water Framework Directive). Official Journal of the European Union L 327: 1-73, 2000.

EUROPEAN PARLIAMENT AND COUNCIL: DIRECTIVE 2010/63/EU of the European Parliament and of the Council of 22 September 2010 on the protection of animals used for scientific purposes. Official Journal of the European Union L 276: 33-79, 2010.

GODOY AA, OLIVEIRA ÁC, SILVA JGM, JESUS AZEVEDO CC, DOMINGUES I, NOGUEIRA AJA, KUMMROW F: Single and mixture toxicity of four pharmaceuticals of environmental concern to aquatic organisms, including a behavioural assessment. Chemosphere 235: 373-382, 2019. https://doi.org/10.1016/j.chemosphere.2019.06.200

HALLING-SØRENSEN B, HOLTEN LÜTZHØFT H-C, ANDERSEN HR, INGERSLEV F: Environmental risk assessment of antibiotics: comparison of mecillinam, trimethoprim and ciprofloxacin. J Antimicrob Chemother 46: 53-58, 2000. https://doi.org/10.1093/jac/46.suppl_1.53

HAMJINDA NS, CHIEMCHAISRI W, WATANABE T, HONDA R, CHIEMCHAISRI CH: Toxicological assessment of hospital wastewater in different treatment processes. Environ Sci Pollut Res 25: 7271-7279, 2015. https://doi.org/10.1007/s11356-015-4812-0

ISO 11348-2: Water quality - Determination of the inhibitory effect of water samples on the light emission of Vibrio fischeri (Luminescent bacteria test) - Part 2: Method using liquid-dried bacteria, 2007.

ISO 15088: Water quality - Determination of the acute toxicity of waste water to zebrafish eggs (Danio rerio), 2007.

ISO 6341: Water quality - Determination of the inhibition of the mobility of Daphnia magna Straus (Cladocera, Crustacea) - Acute toxicity test, 2012.

ISO 7346-2: Water quality - Determination of the acute lethal toxicity of substances to a freshwater fish [Brachydanio rerio Hamilton-Buchanan (Teleostei, Cyprinidae)]-Part 2: Semi-static method, 1999.

ISO 8692: Water quality - Fresh water algal growth inhibition test with unicellular green algae, 2012. 
JIROVA G, VLKOVA A, WITTLEROVA M, DVORAKOVA M, KASPAROVA L, CHRZ J, KEJLOVA K, WITTLINGEROVA Z, ZIMOVA M, HOSIKOVA B, JIRAVOVA J, KOLAROVA H: Toxicity of wastewater from health care facilities assessed by different bioassays. Neuro Endocrinol Lett 39: 441-453, 2018.

JIROVA G, WITTLINGEROVA Z, ZIMOVA M, VLKOVA A, WITTLEROVA M, DVORAKOVA M, JIROVA D: Bioindicators of wastewater ecotoxicity. Neuro Endocrinol Lett 37: 17-24, 2016.

KERN DI, OLIVEIRA SCHWAICKHARDT R, LUTTERBECK CA, KIST LT, ALCAYAGA EAL, MACHADO ÊL: Arch Environ Contam Toxicol 68: 64-73, 2015. https://doi.org/10.1007/s00244-014-0072-0

KIMMEL CHB, BALLARD WW, KIMMEL SR, ULLMANN B, SCHILLING TF: Stages of embryonic development of the zebrafish. Dev Dyn 203: 253-310, 1995. https://doi.org/10.1002/aja.1002030302

KRZYKWA JC, SAEID A, JEFFRIES MKS: Identifying sublethal endpoints for evaluating neurotoxic compounds utilizing the fish embryo toxicity test. Ecotoxicol Environ Saf 170: 521-529, 2019. https://doi.org/10.1016/j.ecoenv.2018.11.118

LAMMER E, CARR GJ, WENDLER K, RAWLINGS JM, BELANGER SE, BRAUNBECK T: Is the fish embryo toxicity test (FET) with the zebrafish (Danio rerio) a potential alternative for the fish acute toxicity test? Comp Biochem Phys C 149: 196-209, 2009. https://doi.org/10.1016/j.cbpc.2008.11.006

LAQUAZ M, DAGOT CH, BAZIN CH, BASTIDE T, GASCHET M, PLOY M-C, PERRODIN Y: Ecotoxicity and antibiotic resistance of a mixture of hospital and urban sewage in a wastewater treatment plant. Environ Sci Pollut Res 25: 9243-9253, 2017. https://doi.org/10.1007/s11356-017-9957-6

LI Q, WANG P, CHEN L, GAO H, WU L: Acute toxicity and histopathological effects of naproxen in zebrafish (Danio rerio) early life stages. Environ Sci Pollut Res 23: 18832-18841, 2016. https://doi.org/10.1007/s11356-016-7092-4

LI S-W, WANG Y-H, LIN AY-C: Ecotoxicological effect of ketamine: Evidence of acute, chronic and photolysis toxicity to Daphnia magna. Ecotoxicol Environ Saf 143: 173-179, 2017. https://doi.org/10.1016/j.ecoenv.2017.05.040

MARTINS N, PEREIRA R, ABRANTES N, GONÇALVES F, MARQUES CR: Ecotoxicological effects of ciprofloxacin on freshwater species: data integration and derivation of toxicity thresholds for risk assessment. Ecotoxicology 21: 1167-1176, 2012. https://doi.org/10.1007/s10646-012-0871-x

MEZA LC, PIOTROWSKI P, FARNAN J, TASKER TL, XIONG B, WEGGLER B, MURRELL K, DORMAN FL, HEUVEL JPV, BURGOS WD: Detection and removal of biologically active organic micropollutants from hospital wastewater. Sci Total Environ 700: 134469, 2020. https://doi.org/10.1016/j.scitotenv.2019.134469

OECD: Test Guideline No. 203: Fish, Acute Toxicity Test. OECD Guidelines for Testing of Chemicals, Section 2, Paris, France, 2019.

OECD: Test Guideline No. 236: Fish Embryo Acute Toxicity (FET) Test. OECD Guidelines for Testing of Chemicals, Section 2, Paris, France, 2013.

ORIAS F, PERRODIN Y: Characterisation of the ecotoxicity of hospital effluents: A review. Sci Total Environ 454-455: 250-276, 2013. https://doi.org/10.1016/j.scitotenv.2013.02.064

PÉREZ-ALVAREZ I, ISLAS-FLORES H, GÓMEZ-OLIVÁN LM, BARCELÓ D, DE ALDA ML, SOLSONA SP, SÁNCHEZ-ACEVES L, SANJUAN-REYES N, GALAR-MARTÍNEZ M: Determination of metals end pharmaceutical compounds released in hospital wastewater from Toluca, Mexico, and evaluation of their toxic impact. Environ Pollut 240: 330-341, 2018. https://doi.org/10.1016/j.envpol.2018.04.116

ROGOWSKA J, CIESZYNSKA-SEMENOWICZ M, RATAJCZYK W, WOLSKA L: Micropollutants in treated wastewater. Ambio 49: 487-503, 2020. https://doi.org/10.1007/s13280-019-01219-5

ROMANUCCI V, SICILIANO A, GALDIERO E, GUIDA M, LUONGO G, LIGUORI R, FABIO G, PREVITERA L, ZARRELLI A. Disinfection by-products and ecotoxic risk associated with hypochlorite treatment of tramadol. Molecules 24: 693, 2019. https://doi.org/10.3390/molecules24040693

SANTOS LHMLM, ARAÚJO AN, FACHINI A, PENA A, DELERUE-MATOS C, MONTENEGRO MCBSM: Ecotoxicological aspects related to the presence of pharmaceuticals in the aquatic environment. J Hazard Mater 175: 45-95, 2010. https://doi.org/10.1016/j.jhazmat.2009.10.100

SCHOLZ S, FISCHER S, GÜNDEL U, KÜSTER E, LUCKENBACH T, VOELKER D: The zebrafish embryo model in environmental risk assessment-applications beyond acute toxicity testing. Environ Sci Pollut Res 15: 394-404, 2008. https://doi.org/10.1007/s11356-008-0018-z 
SOBANSKA M, SCHOLZ S, NYMAN A-M, CESNAITIS R, ALONSO SG, KLÜVER N, KÜHNE R, TYLE H, KNECHT J, DANG Z, LUNDBERGH I, CARLON C, COEN W: Applicability of the Fish Embryo Acute Toxicity (FET) Test (OECD 236) in the Regulatory Context of Registration, Evaluation, Authorisation, and Restriction of Chemicals (REACH). Environ Toxicol Chem 37: 657-670, 2017. https://doi.org/10.1002/etc. 4055

SOKAL RR, ROHLF FJ: Biometry: The Principles and Practice of Statistics in Biological Research. 3rd Edition. W.H. Freeman and Co., New York, 1995, 887 p.

STELZER JAA, ROSIN CK, BAUER LH, HARTMANN M, PULGATI FH, ARENZON A: Is Fish Embryo Test (FET) According to OECD 236 sensible enough for delivering quality data for effluent risk assessment? Environ Toxicol Chem 37: 2925-2932, 2018. https://doi.org/10.1002/etc.4215

TENORIO-CHÁVEZ P, CERRO-LÓPEZ M, CASTRO-PASTRANA LI, RAMÍREZ-RODRIGUES MM, OROZCOHERNÁNDEZ JM, GÓMEZ-OLIVÁN LM: Effects of effluent from a hospital in Mexico on the embryonic development of zebrafish, Danio rerio. Sci Total Environ 727: 1-11, 2020. https://doi.org/10.1016/j.scitotenv.2020.138716

VASCONCELOS EC, DALKE CR, OLIVEIRA CMR: Influence of select antibiotics on Vibrio fischeri and Desmodesmus subspicatus at $\mu \mathrm{g}$ L-1 concentrations. J Environ Manage 60: 157-164, 2017. https://doi.org/10.1007/s00267-017-0841-4

VÄLITALO P, MASSEI R, HEISKANEN I, BEHNISCH P, BRACK W, TINDALL AJ, PASQUIER D, KÜSTER E, MIKOLA A, SCHULZE T, SILLANPÄÄ M: Effect-based assessment of toxicity removal during wastewater treatment. Water Res 126: 153-163, 2017. https://doi.org/10.1016/j.watres.2017.09.014

VERLICCHI P, AL AUKIDY M, ZAMBELLO E: What have we learned from worldwide experiences on the management and treatment of hospital effluent? - An overview and a discussion on perspectives. Sci Total Environ 514: 467-491, 2015. https://doi.org/10.1016/j.scitotenv.2015.02.020

WIEST L, CHONOVA T, BERGÉ A, BAUDOT R, BESSUEILLE-BARBIER F, AYOUNI-DEROUICHE L, VULLIET E: Two-year survey of specific hospital wastewater treatment and its impact on pharmaceutical discharges. Environ Sci Pollut Res 25: 9207-9218, 2018. https://doi.org/10.1007/s11356-017-9662-5

WIGH A, DEVAUX A, BROSSELIN V, GONZALES-OSPINA A, DOMENJOUD B, AÏT-AÏSSA S, CREUSOT N, GOSSET A, BAZIN CH, BONY S: Proposal to optimize ecotoxicological evaluation of wastewater treated by conventional biological and ozonation processes. Environ Sci Pollut Res 23: 3008-3017, 2016. https://doi.org/10.1007/s11356-015-5419-1 